\title{
Seroprevalence of Rickettsia bellii and Rickettsia felis in dogs, Sáo José dos Pinhais, State of Paraná, Brazil
}

\author{
Soroprevalência de Rickettsia bellii e Rickettsia felis em cães, São José dos Pinhais, Paraná, Brasil
}

Fernanda Silva Fortes'; Iara Silveira²; Jonas Moraes-Filho²; Ronaldo Viana Leite'; José Edivaldo Bonacim³; Alexander Welker Biondo ${ }^{4}$; Marcelo Bahia Labruna ${ }^{2}$; Marcelo Beltrão Molento ${ }^{1 *}$

\begin{abstract}
${ }^{1}$ Laboratório de Doenças Parasitárias, Departamento de Medicina Veterinária, Faculdade de Medicina Veterinária, Universidade Federal do Paraná - UFPR

${ }^{2}$ Departamento de Medicina Veterinária Preventiva e Saúde Animal, Faculdade de Medicina Veterinária e Zootecnia, Universidade de São Paulo - USP

${ }^{3}$ Centro de Controle de Zoonoses de São José dos Pinhais - ZCC/SJP

${ }^{4}$ Departamento de Medicina Veterinária, Faculdade de Medicina Veterinária, Universidade Federal do Paraná - UFPR
\end{abstract}

Received July 13, 2010

Accepted November 5, 2010

\begin{abstract}
Brazilian spotted fever (BSF) is a vector-borne zoonosis caused by Rickettsia rickettsii bacteria. Dogs can be host sentinels for this bacterium. The aim of the study was to determine the presence of antibodies against Rickettsia spp. in dogs from the city of São José dos Pinhais, State of Paraná, Southern Brazil, where a human case of BSF was first reported in the state. Between February 2006 and July 2007, serum samples from 364 dogs were collected and tested at 1:64 dilutions by indirect immunofluorescence assay (IFA) against $R$. rickettsii and $R$. parkeri. All sera that reacted at least to one of Rickettsia species were tested against the six main Rickettsia species identified in Brazil: $R$. rickettsii, $R$. parkeri, $R$. bellii, $R$. rhipicephali, $R$. amblyommii and $R$. felis. Sixteen samples (4.4\%) reacted to at least one Rickettsia species. Among positive animals, two dogs (15.5\%) showed suggestive titers for $R$. bellii exposure. One sample had a homologous reaction to $R$. felis, a confirmed human pathogen. Although Rickettsia spp. circulation in dogs in the area studied may be considered at low prevalence, suggesting low risk of human infection, the present data demonstrate for the first time the exposure of dogs to $R$. bellii and $R$. felis in Southern Brazil.
\end{abstract}

Keywords: Brazilian spotted fever, Rickettsia rickettsii, sentinels, indirect immunofluorescence assay.

\section{Resumo}

A febre maculosa brasileira (FMB) é uma zoonose veiculada por carrapatos e causada pela bactéria Rickettsia rickettsii, podendo os cáes ser hospedeiros sentinelas para essa bactéria. O objetivo do estudo foi determinar a presença de anticorpos contra Rickettsia spp. em cães de São José dos Pinhais, estado do Paraná, Sul do Brasil. Entre fevereiro de 2006 e julho de 2007, amostras séricas de 364 cães foram coletadas e testadas na diluição de 1:64 por Reação de Imunofluorescência Indireta (RIFI) contra $R$. rickettsii e $R$. parkeri. Todos os soros reagentes para pelo menos uma espécie de Rickettsia foram testados contra as seis principais espécies de Rickettsia identificadas no Brasil: $R$. rickettsii, $R$. parkeri, $R$. bellii, $R$. rhipicephali, $R$. amblyommii e $R$. felis. Dezesseis amostras $(4,4 \%)$ reagiram para pelo menos uma espécie de Rickettsia. Dos animais positivos, dois cães (15,5\%) apresentaram títulos sugestivos de exposição a $R$. bellii. Uma amostra apresentou reação homóloga frente à $R$. felis, um agente patogênico confirmado para seres humanos. Muito embora os resultados demonstrem uma baixa prevalência de Rickettsia spp. em cáes, sugerindo um baixo risco de infecção humana, este estudo relatou pela primeira vez a evidência de exposição a $R$. bellii e $R$. felis em cáes no Sul do Brasil.

Palavras-chave: Febre maculosa brasileira, Rickettsia rickettsii, sentinelas, reação de imunofluorescência indireta.

\footnotetext{
${ }^{*}$ Corresponding author: Marcelo Beltrão Molento

Laboratório de Doenças Parasitárias, Departamento de Medicina Veterinária,

Faculdade de Medicina Veterinária, Universidade Federal do Paraná - UFPR,

Rua dos Funcionários, 1540, CEP 80035-050, Curitiba - PR, Brazil;

e-mail: molento@ufpr.br
} 


\section{Introduction}

Rickettsia spp. are obligate intracellular bacteria, members of the Rickettsiales order and Rickettsiaceae family (RAOULT; ROUX, 1997). The genus Rickettsia was recently divided into four distinct groups: the spotted fever group (SFG), the typhus group (TG), the transitional group (TRG), and the ancestral group (AG) (GILLESPIE et al., 2007). In Brazil at least seven species of Rickettsia have been described: Rickettsia rickettsii, Rickettsia parkeri, Rickettsia rhipicephali, and Rickettsia amblyommii, all of them from the SFG transmitted through ticks; Rickettsia felis, of TRG, and Rickettsia typhi, of TG, both transmitted through fleas; and Rickettsia bellii, of AG, transmitted through ticks (LABRUNA, 2009).

Although virulence of bacterial genotypes may vary (PAROLA et al., 2009), $R$. rickettsii pathogenicity has been reported in humans and dogs as Rocky Mountain spotted fever (RMSF), a severe clinical disease, also named Brazilian spotted fever (BSF) (LABRUNA et al., 2009). Rickettsia parkeri pathogenicity has also been described in one case of human infection in the United States, and probably in Uruguay (PADDOCK, 2005); moreover, occurrence of human infection has been suggested in Brazil (LABRUNA, 2009). Rickettsia felis and $R$. typhi are also pathogenic in humans, although $R$. rickettsii infection is relatively more severe (PAROLA et al., 2005). Other rickettsial species described in Brazil ( $R$. bellii, $R$. rhipicephali e $R$. amblyommii) have never been associated to human disease; however, $R$. amblyommii has been recently incriminated as the causative agent of febrile disease in humans in the United States (APPERSON et al., 2008).

Ticks of the Amblyomma genus are the main vectors of BSF, notably Amblyomma cajennense and Amblyomma aureolatum (PINTER; LABRUNA, 2006). In general, this genus is characterized by low host specificity, particularly in their immature stages. Some domestic animals, such as horses and dogs, are important amplifier hosts of ticks and serve as sentinels for Rickettsiae species (SANGIONI et al., 2005). Domestic dogs may play an important epidemiological role in the urban cycle of this disease due to household carriage of infected ticks and closer contact with their owners (PIRANDA et al., 2008).

Serological studies in several Brazilian States have indicated previous exposure of dogs to $R$. rickettsii, sentinel hosts for bacterial dissemination (HORTA et al., 2004; SANGIONI et al., 2005; LABRUNA et al., 2007a). Information based on serological surveys for $R$. rickettsii in sentinel animals may identify new endemic areas of BSF where the population can be properly warned about the risk of this disease (PADDOCK et al., 2002).

The occurrence of BSF by $R$. rickettsii has been reported in Brazil since the 1920s. The disease has been classically reported in the southeastern region, presenting a severe form which may evolve to death when patients are left untreated or receive late treatment. BSF is currently considered a reemerging zoonosis with high prevalence in the States of Minas Gerais and São Paulo (PINTER et al., 2008). Recently the disease has been first reported in humans in all three Brazilian Southern States. However, different from the 18 to $30 \%$ lethality found in southeastern Brazil (ANGERAMI et al., 2006; CALIC et al., 2005), no deaths were seen in human cases reported in the Southern region. In addition, local epidemiological differences such as absence of A. cajennense in most Southern States (ESTRADA-PEÑA et al., 2004; EVANS et al., 2000) suggest that the etiological agent of BSF in southern region of Brazil may be other than $R$. rickettsii.

The first case in humans in the State of Paraná was reported in 2005 in the city of São José dos Pinhais in the suburban area of the state capital of Curitiba. A recent serum surveillance study on cart horses used for carrying recyclable material has demonstrated the presence of antibodies against $R$. rickettsii (FREITAS et al., 2010). Although dogs are considered an important sentinel for BSF, no previous study has been conducted on dogs in that area.

The aim of the present study was to examine dogs received by the Zoonosis Control Center of São José dos Pinhais (ZCC/SJP) for the presence of antibodies against Rickettsia spp.

\section{Material and Methods}

\section{Area of study}

The present study was conducted in the municipality of Sáo José dos Pinhais (Figure 1), located in the metropolitan area of Curitiba, Paraná State capital, Southern Brazil (2532' $05^{\prime \prime} \mathrm{S}$ and $\left.49^{\circ} 12^{\prime} 23^{\prime \prime} \mathrm{W}\right)$. The city has an altitude of 906 meters above sea level and an area of $946 \mathrm{~km}^{2}$ of which about $40 \%$ is protected native Atlantic forest. The estimated population is about 263,622 residents (demographic density of 276 inhab $/ \mathrm{km}^{2}$ ), $90 \%$ of which living in the urban area. The weather is described as humid subtropical with annual average temperatures of $16^{\circ} \mathrm{C}$ (IBGE, 2007).

\section{Animals}

From February 2006 to July 2007 a total of 364 dogs, of which 192 from 34 urban areas, 129 from 31 rural areas and 43 with unknown origin were received at the Zoonosis Control

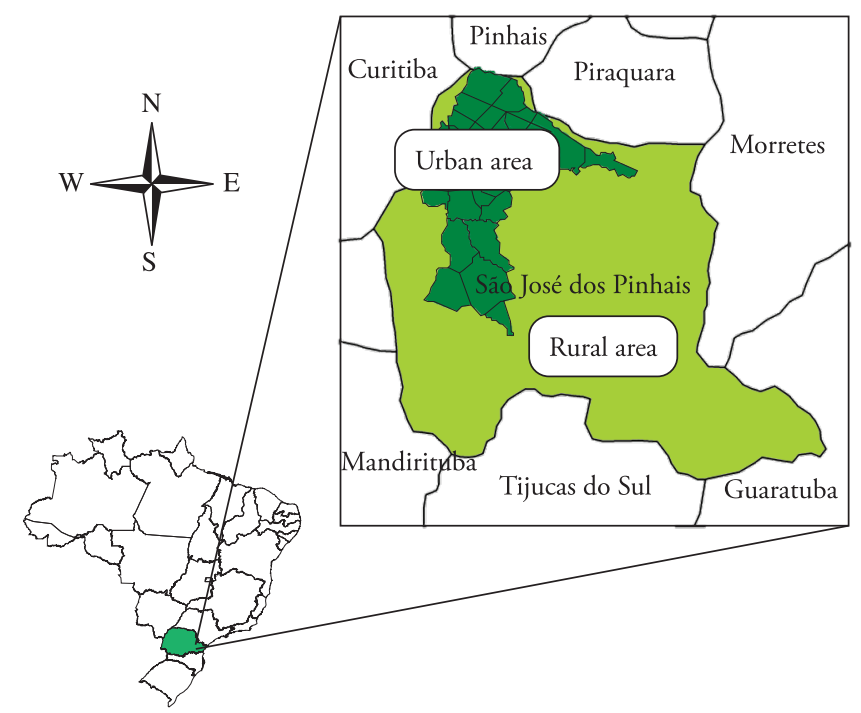

Figure 1. Rural and urban areas in the city of São José dos Pinhais, State of Paraná, Southern Brazil. 
Center (ZCC) of São José dos Pinhais. Of all, 222 were stray dogs captured on streets, and 142 were domiciled dogs whose owners have requested them to be removed. The animals were physically restrained and sedated with ketamine chloride $\left(10 \mathrm{mg} \cdot \mathrm{kg}^{-1}\right)$ and xylazine chloride $\left(1 \mathrm{mg} \cdot \mathrm{kg}^{-1}\right)$ intramuscularly. Following initial sedation, $12.5 \mathrm{mg} \cdot \mathrm{kg}^{-1}$ of sodium thiopental was intravenously administered and blood was drawn prior to euthanasia. Whole blood samples were then collected by intracardiac puncture, centrifuged at 3,000 rpm for 5 minutes, and serum samples were stored at $-20{ }^{\circ} \mathrm{C}$ in $1.5 \mathrm{~mL}$ Eppendorf tubes until analysis. A data file was created for each dog, including the day of blood sampling, sex, age (young, adult, or old), breed and ownership status.

The present study was approved by the Animal Ethics Committee (Protocol \# 037/2008) of the Department of Agricultural Sciences at the Universidade Federal do Paraná.

\section{Indirect immunofluorescence assay (IFA)}

Indirect immunofluorescence assay (IFA) was performed following previous standard protocol (HORTA et al., 2004). In brief, the test consisted of serum samples reaction with VERO cells infected with Rickettsia spp. that were isolated from native Brazilian ticks. Each serum was individually screened at 1:64 dilution of antigens of $R$. rickettsii (strain Taiacu) and $R$. parkeri (strain AT24). Fluorescein isothiocyanate anti-dog immunoglobulin G (Antibodies, Zoonosis Control Center, São Paulo, Brazil) was applied for fixed antigen reaction and visualized by fluorescence microscope (Olympus BX60; Olympus, Tokyo, Japan). Positive and negative sera were used as controls for each slide reaction. Positive samples for at least one tested species were then submitted to serial dilutions until 1:1024 and tested against antigens of $R$. rickettsii (strain Taiacu), $R$. parkeri (strain AT24), $R$. bellii (strain Mogi), R. rhipicephali (strain $\mathrm{HJ} 5$ ), $R$. amblyommii (strain Ac37), and $R$. felis (strain Pedreira). Samples with IgG titers $\geq 1: 64$ were considered positive, as previously described for humans and dogs (SANGIONI et al., 2005). Samples with titers at least fourfold higher for a specific Rickettsia when compared to others were considered homologous or very closely related genotype (SAITO et al., 2008).

\section{Statistics}

Statistical analysis was conducted using the chi-square test (BioEstat $5.0^{\circ}$, National Council for Scientific and Technological Development [CNPq], Brazil). IFA results for Rickettsia spp. were also correlated by sex, age, breed and ownership status. Differences in the multivariate model were considered of statistical significance when $\mathrm{p}<0.05$.

\section{Results}

A total of 364 dogs were sampled and tested against $R$. rickettsii and $R$. parkeri antigens at 1:64 dilution, of which $16(4.4 \%)$ reacted to at least one of the two species. Out of 16 initially positive samples, nine were positive against $R$. parkeri, seven against $R$. rickettsii, five against $R$. felis, five against $R$. amblyommii, four against $R$. bellii, and three against $R$. rhipicephali (Table 1). Among positive dogs, two had suggestive titers of $R$. bellii exposure, and one sample showed a homologous reaction to $R$. felis.

A total of 09/34 (26.5\%) urban districts in São José dos Pinhais had at least one positive animal for Rickettsia spp. (Table 2 and Figure 2). Although one animal was from an unknown origin, no positive animal $(0 / 31)$ was found from rural areas.

Table 1. Endpoint titers of indirect immunofluorescence assay (IFA) against antigens of six Rickettsia species in dog sera. City of São José dos Pinhais, State of Paraná, Southern Brazil, February 2006-2007.

\begin{tabular}{|c|c|c|c|c|c|c|c|}
\hline \multirow[t]{2}{*}{ Serum } & \multicolumn{6}{|c|}{ Endpoint IgG titers } & \multirow[t]{2}{*}{ PAIHR } \\
\hline & R. rickettsii & R. parkeri & R. bellii & R.felis & R. amblyommii & R. rhipicephali & \\
\hline 8 & 64 & - & - & 64 & - & - & \\
\hline 27 & - & - & - & 64 & - & - & \\
\hline 86 & - & 128 & - & - & - & 64 & \\
\hline 103 & - & - & 128 & - & - & - & R. bellii \\
\hline 107 & - & 64 & - & - & - & - & \\
\hline 138 & 256 & 128 & - & - & 128 & 128 & \\
\hline 145 & - & - & 1024 & - & - & - & R. bellii \\
\hline 162 & 64 & 128 & - & - & - & - & \\
\hline 163 & - & 64 & - & - & - & - & \\
\hline 183 & 64 & 64 & 64 & 128 & - & - & \\
\hline 204 & 64 & - & - & - & 64 & - & \\
\hline 244 & - & - & - & - & 64 & - & \\
\hline 295 & 256 & 128 & - & - & 128 & 128 & \\
\hline 344 & - & - & - & 128 & - & - & R. felis \\
\hline 346 & - & 128 & 64 & 64 & - & - & \\
\hline 354 & 128 & 256 & - & - & 64 & - & \\
\hline
\end{tabular}

PAIHR: Possible antigen involved in a homologous reaction. Sera evidencing Rickettsia species titer at least fourfold higher than that observed for any other Rickettsia species were considered homologous to the first Rickettsia species. Therefore, dogs 8, 27, 86, 107, 138, 162, 163, 183, 204, 244, 295, 346, 354 were not considered PAIHR. -: Non reactive at IgG titer $\geq 1: 64$; IFA: indirect immunofluorescence assay. 
Out of the positive samples, $10(62.5 \%)$ were males and six $(37.5 \%)$ were females; $15(93.7 \%)$ were adults and one $(6.2 \%)$ was old. Eleven dogs (68.7\%) were from mixed breed, two were Rottweiler, one German shepherd, one cocker spaniel, and one pit bull.

No differences were found when the 360 dogs were compared by age (young, adult, or old; $x^{2}=0.196$ ), sex (male, female; $x^{2}=0.047$ ), breed (pure breed, mixed breed; $x^{2}=0.223$ ) or ownership (stray and owned; $x^{2}=0.016$ ).

Table 2. Distribution of positive dogs (IgG titers $\geq 64$ by indirect immunofluorescence assay) per district. City of São José dos Pinhais, State of Paraná. Southern Brazil, 2006-July 2007.

\begin{tabular}{lccc}
\hline \multirow{2}{*}{ Neighborhood } & \multicolumn{2}{c}{ Dogs (positive/total tested) } & Total \\
\cline { 2 - 3 } & $\mathbf{2 0 0 6}$ & $\mathbf{2 0 0 7}$ & \\
\hline Afonso Pena & $1 / 16$ & $0 / 15$ & $1 / 31(3.2 \%)$ \\
Borda do Campo & $2 / 10$ & $0 / 1$ & $2 / 11(18.2 \%)$ \\
Rio Grande & $1 / 4$ & $1 / 2$ & $2 / 6(33.3 \%)$ \\
Cruzeiro & $2 / 3$ & $0 / 6$ & $2 / 9(22.2 \%)$ \\
Independência & $1 / 2$ & $0 / 0$ & $1 / 2(50.0 \%)$ \\
Itália & $2 / 10$ & $0 / 2$ & $2 / 12(16.7 \%)$ \\
Centro & $1 / 19$ & $2 / 10$ & $3 / 29(10.3 \%)$ \\
Rio Pequeno & $1 / 7$ & $0 / 0$ & $1 / 7(14.3 \%)$ \\
Ipê & $0 / 5$ & $1 / 4$ & $1 / 9(11.1 \%)$ \\
\hline
\end{tabular}

\section{Discussion and Conclusion}

The present study found a relatively low prevalence of antibodies to Rickettsia spp. (4.4\%) when compared to previous serological studies performed in dogs from endemic areas in the State of São Paulo that reported a seropositivity between 31.3 and $69.6 \%$ (LEMOS et al., 1996; HORTA et al., 2004, 2007; PINTER et al., 2008; MORAES-FILHO et al., 2008), from endemic areas of the State of Minas Gerais (13.7 and 81.3\%) (LEMOS et al., 1994; VIANNA et al., 2008) and from endemic areas of the State of Espírito Santo (7.6\%) (SPOLIDORIO et al., 2010). The seroprevalence found in the present study was also lower than that reported in dogs from non-endemic areas, $12.9 \%$ (LEMOS et al., 1996) and 20\% (HORTA et al., 2007) in the State of São Paulo, and 11 to $23 \%$ in Northern Paraná (TAMEKUNI, 2009). These studies have shown the importance of dogs as sentinels for human infection and how wide may be the geographic distribution of BSF due to this interaction.

The relatively lower overall prevalence found corroborates a single previous report to date of a human case in the same municipality (FREITAS et al., 2010). However, when positive dogs were distributed by district, the seropositivity varied from 3.2 to $50.0 \%$. The human case was reported in the district of Borda do Campo (18.2\%) (Table 2). Thus, regular monitoring is required because, despite the low prevalence found in the present
Number of seropositive animals

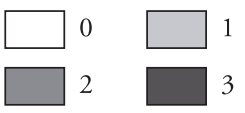

*Occurrence area of the $1^{\text {st }}$ human case of BSF in Paraná

Urban areas
1. Centro

2. Sáo Domingos

3. Cidade Jardim

4. São Cristóváo

5. Sáo Pedro

6. Bom Jesus

7. Pedro Moro

8. Aristocrata

9. Águas Betas

10. Boneca do Iguaçu

11. Afonso Pena

12. Aviaçáo

13. Aeroporto

14. Quissisana

15. Cruzeiro

16. Ouro Fino

17. Itália

18. Santo Antônio

19. Rio Grande

20. Zacarias

21. Arujá
22. Barro Preto
23. Costeira
24. Costeirinha
25. Rio Pequeno
26. Iná
27. Independência
28. Ipê
29. Guatupê
30. Cristal
31. Academia
32. Roseira de Sáo Sebastiáo
33. Borda do Campo
34. Dom Rodrigo
35. Del Rey
36. Sáo Marcos
37. Campina do Taquaral
38. Passo do Campo
39. Campo Largo da Roseira
40. Contenda

40. Contenda

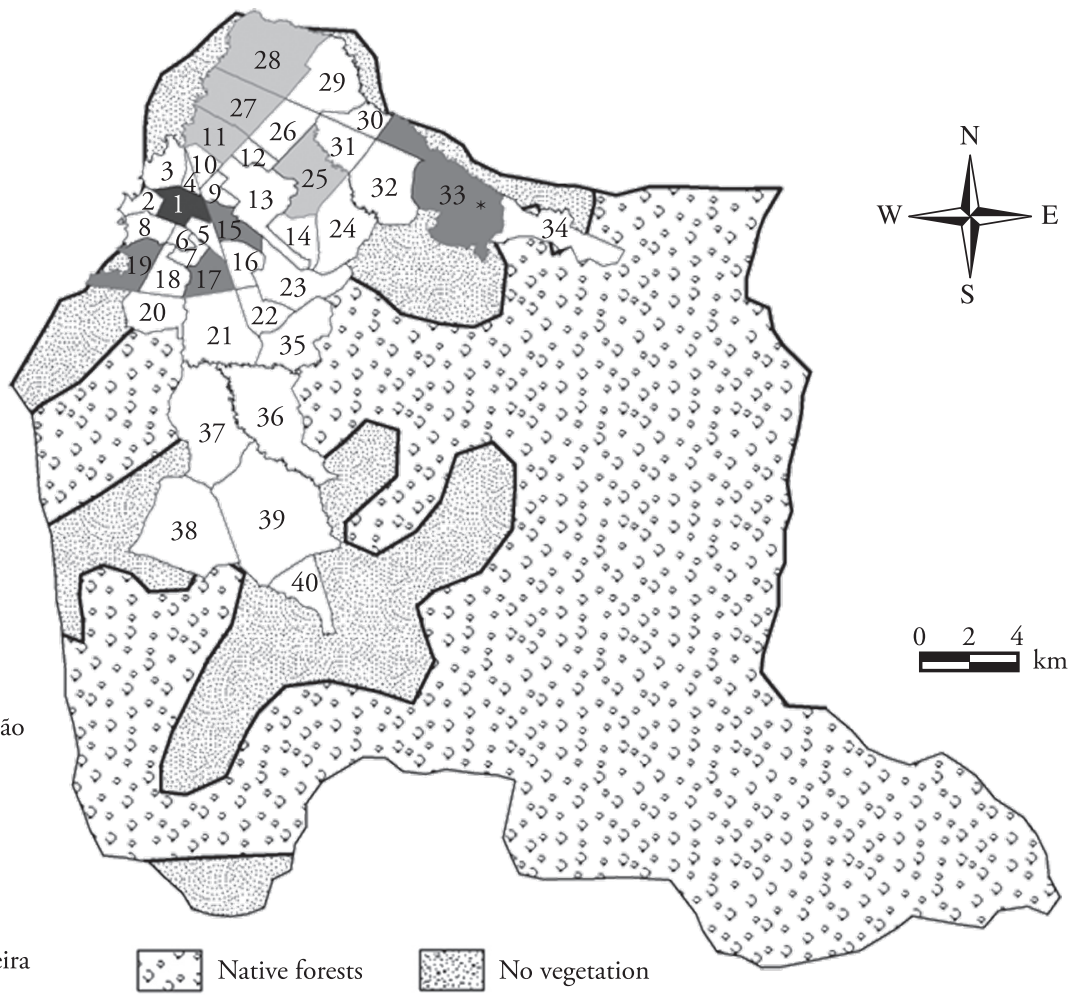

Figure 2. Positive dogs sera by indirect immunofluorescence assay (IFA) for Rickettsia spp., according to areas where at least one dog was found positive. City of São José dos Pinhais. State of Paraná, Southern Brazil, 2006-2007. 
study, it may represent an important finding since BSF frequency may vary due to seasonal distribution of local vectors.

All positive samples came from the urban area of São José dos Pinhais, which contrast with that reported by Labruna et al. (2007a) who showed 11.6 and 3.9\% prevalence of antibodies against Rickettsia spp. in rural and urban areas in Northern Brazil. Although forest areas are common in the region studied (dog origin) (Figure 2) and may favor tick proliferation (SAITO et al., 2008), no positive animal was found in the rural area. The fact that seropositive dogs were found only in urban areas may be explained by tick distribution associated to higher concentration of host species in these areas. Since it was out of the scope of the present study to determine tick species and their frequency, further studies are needed to fully establish this correlation.

Another serological survey conducted in 389 dogs of Southern Brazil have shown a high prevalence of positive animals (42.4\%) for Rickettsia spp. by IFA, and R. parkeri was the causative agent in 100/389 (25.7\%) dogs (SAITO et al., 2008). We hypothesize that low titers may be a result of a less recent or severe infection, probably due to low or non-pathogenic Rickettsia species.

The present data shows no infection evidence for either $R$. rickettsii or $R$. parkeri. Even in endemic areas of Southern Brazil, previous studies have proposed that BSF may be caused by Rickettsia species other than $R$. rickettsii. Moreover, regional particularities may also play a role such as host species, tick prevalence and risk of human exposure to potential infected vectors (PACHECO et al., 2007).

This is the first report on evidence of natural infection by $R$. bellii and R. felis in dogs from Southern Brazil. Rickettsia bellii has been reported in ticks of Southeastern Brazil (LABRUNA et al., 2004; HORTA et al., 2006) and Amblyomma ticks from rural areas of Brazil are mostly infected by R. bellii (PINTER et al., 2008). However, the first evidence in vertebrates has been only recently reported, and only in capybaras from the same region (PACHECO et al., 2007). Although strictly associated to ticks, $R$. bellii is not classified as belonging to the SFG group and its pathogenic effects in humans and dogs has never been demonstrated.

Serological evidence of infection by $R$. bellii in two dogs and $R$. felis in another animal may indicate that these two agents are probably circulating in the region. In addition, since $R$. felis is reportedly pathogenic for human in southeastern Brazil (PAROLA et al., 2005), these findings may alert of zoonotic risk in the area.

Although most reports on $R$. felis were associated to the flea Ctenocephalides felis felis collected in cats and/or dogs (LABRUNA et al., 2007b; NAVA et al., 2008; OLIVEIRA et al., 2008; GEHRKE et al., 2009), future studies should be conducted to fully establish flea rickettsial burden.

It was first evidenced dog exposure by $R$. bellii and $R$. felis in Southern Brazil, demonstrating Rickettsia circulation in the area. The low prevalence found in the study suggests that dogs are exposed to a small vector population infected by Rickettsia and the risk of infection for humans may be low too. However, active epidemiological surveillance should be periodically conducted as the area is considered vulnerable to BSF cases.

\section{Acknowledgments}

Fernanda Silva Fortes was supported by the Conselho Nacional de Desenvolvimento Científico e Tecnológico (CNPq). We kindly thank the support team from the Zoonosis Control Center of Sáo José dos Pinhais, State of Paraná, for their help with animal handling.

\section{References}

ANGERAMI, R. N. et al. Brazilian spotted fever: a case series from an endemic area in southeastern Brazil: epidemiological aspects. Annals of the New York Academy of Sciences, v. 1078, n. 1, p. 170-172, 2006.

APPERSON, C. S. et al. Tick-borne diseases in North Carolina: is "Rickettsia amblyommii" a possible cause of rickettsiosis reported as Rocky Mountain spotted fever? Vector-Borne and Zoonotic Diseases, v. 8, n. 5, p. 597-606, 2008.

CALIC, S. B. et al. Old and new human rickettsiosis in Minas Gerais state, Brazil. Annals of the New York Academy of Sciences, v. 1063, n. 1, p. 356-357, 2005.

ESTRADA-PEÑA, A.; GUGLIELMONE, A. A.; MANGOLD, A. J. The distribution and ecological "preferences" of the tick Amblyomma cajennense (Acari: Ixodidae), an ectoparasite of humans and other mammals in the Americas. Annals of Tropical Medicine and Parasitology, v. 98, n. 3, p. 283-292, 2004.

EVANS, D. E.; MARTINS, J. R.; GUGLIELMONE, A. A. A review of the ticks (Acari: Ixodida) of Brazil, their hosts and geographic distribution-1. The state of Rio Grande do Sul, Southern Brazil. Memórias do Instituto Oswaldo Cruz, v. 95, n. 4, p. 453-470, 2000.

FREITAS, M. C. D. O. et al. Brazilian Spotted Fever in Cart Horses in a non-endemic area in the Southern Brazil. Revista Brasileira de Parasitologia Veterinária, v. 19, n. 2, p. 130-131, 2010.

GEHRKE, F. S. et al. Rickettsia rickettsii, Rickettsia felis and Rickettsia sp. TwKM03 infecting Rhipicephalus sanguineus and Ctenocephalides felis collected from dogs in a Brazilian spotted fever focus in the State of Rio de Janeiro/Brazil. Clinical Microbiology and Infection, v. 15, n. 2, p. 267-268, 2009.

GILLESPIE, J. J. et al. Plasmids and rickettsial evolution: insight from Rickettsia felis. PLoS One, v. 2, n. 3, e266, 2007.

HORTA, M. C. et al. Prevalence of antibodies to spotted fever group Rickettsiae in humans and domestic animals in a Brazilian spotted fever-endemic area in the State of São Paulo, Brazil: serologic evidence for infection by Rickettsia rickettsii and another spotted fever group Rickettsia. American Journal of Tropical Medicine and Hygiene, v. 71, n. 1, p. 93-97, 2004.

HORTA, M. C. et al. Natural infection, transovarial transmission, and transstadial survival of Rickettsia bellii in the tick Ixodes loricatus (Acari: Ixodidae) from Brazil. Annals of the New York Academy of Sciences, v. 1078, n.1, p. 285-290, 2006.

HORTA, M. C. et al. Rickettsia infection in five areas of the State of São Paulo, Brazil. Memórias do Instituto Oswaldo Cruz, v. 102, n. 7, p. 793-801, 2007.

IBGE. São José dos Pinhais. Disponível em: <http://www.ibge.gov.br>. Acesso em 24/02/2007. 
LABRUNA, M. B. Ecology of Rickettsia in South America. Annals of the New York Academy of Sciences, v. 1166, n. 1, p. 156-166, 2009.

LABRUNA, M. B.et al. Rickettsia species infecting Amblyomma cooperi ticks from an area in the State of São Paulo, Brazil, where Brazilian spotted fever is endemic. Journal of Clinical Microbiology, v. 42, n. 1, p. $90-98,2004$.

LABRUNA, M. B. et al. Prevalence of Rickettsia infection in dogs from the urban and rural areas of Monte Negro Municipality, western Amazon, Brazil. Vector Borne and Zoonotic Diseases, v. 7, n. 2, p. 249-255, 2007a.

LABRUNA, M. B. et al. Rickettsia felis in Chile. Emerging Infectious Diseases, v. 13, n. 11, p. 1794-1795, 2007 b.

LABRUNA, M. B. et al. Rocky Mountain spotted fever in dogs, Brazil. Emerging Infectious Diseases, v. 15, n. 3, p. 458-460, 2009.

LEMOS, E. R. S. et al. Epidemiological aspects of the Brazilian spotted fever: serological survey of dogs and horses in an endemic area in the state of São Paulo, Brazil. Revista do Instituto de Medicina Tropical de Sáo Paulo, v. 38, n. 6, p. 427-430, 1996.

LEMOS, E. R. S.; MACHADO, R. D.; COURA, J. R. Rocky Mountain spotted fever in an endemic area in Minas Gerais, Brazil. Memórias do Instituto Oswaldo Cruz, v. 89, n. 4, p. 497-501, 1994.

MORAES-FILHO, J. et al. New Epidemiological Data on Brazilian Spotted Fever in an Endemic Area of the State of São Paulo, Brazil. Vector Borne and Zoonotic Diseases, 2008. Epud ahead of print.

NAVA, S. et al. Rickettsia felis in Ctenocephalides felis from Argentina. Vector Borne and Zoonotic Diseases, v. 8, n. 4, p. 465-466, 2008.

OLIVEIRA, K. A. et al. Molecular identification of Rickettsia felis in ticks and fleas from an endemic area for Brazilian Spotted Fever. Memórias do Instituto Oswaldo Cruz, v. 103, p. 191-194, 2008.

PACHECO, R. C. et al. Rickettsial infection in capybaras (Hydrochoerus hydrochaeris) from São Paulo, Brazil: serological evidence for infection by Rickettsia bellii and Rickettsia parkeri. Biomédica, v. 27, n. 3, p. 364-371, 2007.

PADDOCK, C. D. et al. Assessing the magnitude of fatal Rocky Mountain spotted fever in the United States: comparison of two national data sources. American Journal of Tropical Medicine and Hygiene, v. 67, n. 4 , p. 349-354, 2002.
PADDOCK, C. D. Rickettsia parkeri as a paradigm for multiple causes of tick-borne spotted fever in the western hemisphere. Annals of the New York Academy of Sciences, v. 1063, n. 1, p. 315-326, 2005.

PAROLA, P.; DAVOUST, B.; RAOULT, D. Tick- and flea-borne rickettsial emerging zoonosis. Veterinary Research, v. 36, n. 3, p. 469-492, 2005.

PAROLA, P.; LABRUNA, M. B.; RAOULT, D. Tick-Borne rickettsioses in America: Unanswered questions and emerging diseases. Current Infectious Disease Reports, v. 11, n. 1, p. 40-50, 2009.

PINTER, A. et al. Serosurvey for Rickettsia spp. in dogs and humans from an endemic area for Brazilian spotted fever in the state of São Paulo. Cadernos de Saúde Pública, v. 24, n. 2, p. 247-252, 2008.

PINTER, A.; LABRUNA, M. B. Isolation of Rickettsia rickettsii and Rickettsia bellii in cell culture from the tick Amblyomma aureolatum in Brazil. Annals of New York Academy of Sciences, v. 1078, n.1, p. 523-529, 2006.

PIRANDA, E. M. et al. Experimental infection of dogs with a Brazilian strain of Rickettsia rickettsii: clinical and laboratory findings. Memórias do Instituto Oswaldo Cruz, v. 103, n.7, p. 696-701, 2008.

RAOULT, D.; ROUX, V. Rickettsioses as paradigms of new or emerging infectious diseases. Clinical Microbiology Reviews, v. 10, n. 4, p. 694-719, 1997.

SAITO, T. B. et al. Canine Infection by Rickettsiae and Ehrlichiae in Southern Brazil. American Journal of Tropical Medicine and Hygiene, v. 79 , n. 1, p. 102-108, 2008.

SANGIONI, L. A. et al. Rickettsial infection in animals and Brazilian spotted fever endemicity. Emerging Infectious Diseases, v. 11, n. 2, p. 265-270, 2005.

SPOLIDORIO, M. G. et al. Survey for tick-borne zoonoses in the state of Espirito Santo, southeastern Brazil. American Journal of Tropical Medicine and Hygiene, v. 83, n. 1, p. 201-206, 2010.

TAMEKUNI, K. Prevalência de anticorpos contra rickettsias do grupo da Febre Maculosa em humanos, cáes e equinos e identificação molecular de Rickettsia spp. em carrapatos na regiáo Norte do Paraná. 2009. 76 f. Tese (Doutorado)-Universidade Estadual de Londrina, Londrina. 2009.

VIANNA, M. C. B. et al. Rickettsial spotted fever in Capoeirão Village, Itabira, Minas Gerais, Brazil. Revista do Instituto de Medicina Tropical de Sáo Paulo, v. 50, n. 5, p. 297-301, 2008. 